Saeculum Christianum

vol. XXII (2015)

pp. $136-152$

MALGORZATA PĘGIER*

WNHiS UKSW, Warszawa

\title{
THE REPORT FROM THE CHRONICLE BY STEFAN RANATOWICZ CRL (1617-1694) ON THE BIOGRAPHIES OF THE PROVOSTS OF THE CORPUS CHRISTI MONASTERY OF CANONS REGULAR OF THE LATERAN OF THE CRACOW CONGREGATION (FROM KONRAD ALEMAN TO WIKTORYN WERESZCZYŃSKI)
}

The author of the Chronicle, father Stefan Ranatowicz, was a seventeenth-century chronicler and a historian of the Corpus Christi congregation of Canons Regular of the Lateran monastery in Kazimierz near Cracow. He lived in the years 1617-1694, he studied at the Cracow Academy in the years 1635-1636, and in 1636 he joined the congregation of regular canons. He performed many functions in the monastery and was a canon who distinquished himself not only by his piety but also by his education, as evidenced by his works. His only work issued in print was the life of the blessed Stanisław Kazimierczyk, published in 1660 in Cracow ${ }^{1}$. The chronicle with a Latin title, starting with the words: Casimiriae civitatis, urbi Cracoviensi confrontatae, origo $[\ldots]^{2}$ was written mainly as a record of the history of the congregation, whereas its main and at the same time foundamental part, is shaped by biographies of subsequent provosts of the Cracow congregation, starting with Konrad Aleman, the first ruler of the monastery, and ending with Wiktoryn Wereszczyński, who died a few months after the death of the author, Stefan Ranatowicz.

There are 13 biographies discussed in the Chronicle, whereby the last one was not written by Ranatowicz. Apart from the history and achievements of subsequent provosts of the Corpus Christi monastery the chronicler presented also the events that took place at that

\footnotetext{
* Translated by Spektra Sp. z o.o.

1 S. Ranatowicz, Jasna Pochodnia życia apostolskiego. Żywot świątobliwy Stanisława Kazimierczyka, Kraków 1660; see also: A. Witkowska, J. Nastalska, Staropolskie piśmiennictwo hagiograficzne, Lublin 2007.

2 The full Latin title of the Chronicle is: Casimiriae civitatis, urbi Cracoviensi confrontatae, origo. in eaque ecclesiarum erectiones et religiosorum fundationes, nec non series, vitae, res gestae praepositorum Conventus Canonicorum Regularium Lateranensium S[ancti] Augustini ad Ecclesiam S[acratis]S[imi] Corporis Christi descriptae a Stephano Ranothowicz eiusdem conventus et Ecclesiae Canonico Regul[ari] professo. The chronicle has the form of a code with dimensions of $30.2 \times 19.5 \mathrm{~cm}$. The binding is cardboard, covered with dark brown veal leather. The decorations are only embossed, devoid of any gildings - it is a plant ornament in several frames and a monogram of IHS [Iesus Hominum Salvator]. On the front external side of the luminaire there is also an inscription made with a majuscule: ,PRO CONVENTU CAN[ONICORUM] REG[ULARIUM] S[ACRAIS]S[IMI] CORPOIS CHRI[STI]". Today the Chronicle is in the manuscript collection of the Jagiellonian Library, BJ, sygn. 3742.
} 
time, regarded by him as worth noting and a list of canons who died during the governance of particular provosts. However, the author did not limit himself to presenting the lives of provosts and their terms of office but he also wrote about the features of character and even assessed the conduct of the presented figures. Therefore, these are in a sense portraits. They were edited in quite a uniform way: they started with the information on the choice of the position and were followed by a discussion of the spiritual figure and the origin of the provost, then the governance was characterised, and information on specific activities and monastery events, often also external ones was provided, at the end there was information on death. The amount of information included in particular portraits is growing when the author approaches the times contemporary to him, which meant that the source materials, accessible to him, were expanding. Therefore, the biographies of the first provosts are much shorter and poorer in detail than the last ones, especially when some of the described events were recollected by the author himself and that he remembered the persons who witnessed them. It is not possible to present in one article the full content of individual lives, and above all, to present all the stories described by the author, therefore only the most important achievements of the provosts and events that seem to be particularly interesting are mentioned here. It wasn't the intention of the author to present the actual achievements of subsequent provosts, since the theme has already been thoroughly elaborated by researchers dealing with the history of the Congregation of Canons Regular the Lateran, as for example in the work of father prof. Kazimierz Łatak Kongregacja Kanoników Regularnych Laterańskich na przestrzeni dziejów. The work includes only facts or the ways they are perceived, in the light of the Chronicle of father Stefan Ranatowicz and his relations.

The first provost of the conent of Canons Regular of the Corpus Christi provostry was Konrad Alemanus (1405-1425). Ranatowicz evaluated his governance positively and he also praised him writing that he maintained good relations with his brothers in the Corpus Christi convent and stated that he deserved the recognition of his superiors ${ }^{3}$. When it comes to the governance of Konrad Aleman, the chronicler referred several times to the manuscripts which remained after Krzysztof Łoniewski ${ }^{4}$. While describing the construction of the Corpus Christi Church, he quoted the information provided by Jan Długosz, concerning the wooden parish church and its dismantling in order to build a new stone and brick temple. Moreover, he explained how one should understand the provided information ${ }^{5}$. In his opinion, Konrad removed only the wooden superstructure which made it possible to unveil the walls erected during the reign of Casimir the Great. The chronicler additionally noted that the provost practised the establishment of confraternity with both clergy and lay people $^{6}$ and emphasised that the discipline of life in the monastery was based on religious statutes ${ }^{7}$. The death of Konrad Aleman was noted by Ranatowicz under the year 1421: Conradus praepositus, in officio praepositurae sexdecem annis expletis, cum omnia a se optime constituta et ordinata, sancte et laudabiliter transegisset, tandem bonis operibus plenus, senio et laboribus confectus, cum ante mortem sacramentis Ecclesiasticis, contra

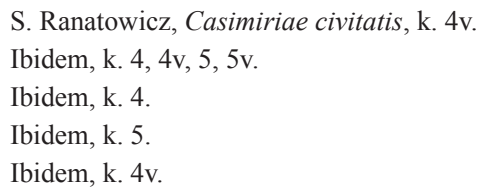


supremum certamen se religiose munivisset, vitam mortalem cum immortali commutavit. Sepultus honorifice ante maius altare Ecclesiae ${ }^{8}$, when in fact he died as late as in $1525^{9}$. Ranatowicz probably made a mistake in reading the date from the tombstone by confusing the numbers 1 with 4 in gothic writing, because the death of the provost was originally dated to 1424. However, it was Krzysztof Łoniewski who dated the indicated death to 1425, which should finally be accepted as proper. The part devoted to Konrad Aleman ends with records from various years, disordered chronologically, referring to various issues, such as for example the earthquake in Poland, the fire in Cracow, the Tatar attack, the plague or great famine. These are frequently short entries, such as, for example Anno D[omi] ni 1124. Cracovia tota conflagrata; Anno D[omi]ni. Sal in Civitate Bochnensi inventus 1230; Anno D[omi]ni 1310. Pestis et terrae motus ${ }^{10}$. The indicated notes give the impression of the Annal-type entries. However, it was not possible to establish the source of their origin. It is possible that, Stefan Ranatowicz used the documents collected in the minucipal archive, especially considering the fact that Jan Fox, acting as a Chancellor of the Cracow Chapter, visited the Canon Monastery in Kazimierz.

Jan Austriak (1425-1429) was the next provost. Stefan Ranatowicz did not pay too much attention to him, and the information provided concerning the activity of the indicated figure is rather scarce. He explained that by a small number of available materials left by the monks from that time: Caetera quae ioannes Austriacus, praepositus, fecit, antiqui fratres non scripsere ${ }^{11}$. However, he noted that Jan Austriak entered into numerous confraternities with other canon monasteries and mentions the institutions in Trzemeszno, Mstów and Kalisz. In addition, during the governance of the indicated provost the monastery received the confirmation of its establishment from the Pope Martin $\mathrm{V}^{12}$. He did not provide any details on the construction of the church except the information that the work commenced by Konrad Aleman was continued. Additionally, the text includes the information on the introduction of a daily reading habit of monastery statutes by Jan Austriak in the Kazimierz convent developed by Piotr Klareta from the house in Rudnice ${ }^{13}$. Ranatowicz assessed that Jan Austriak took great care of the monastic rule and ritual ${ }^{14}$. He dated the death of the provost to $1428^{15}$. Apart from that, there are also annal records from various years. Those are both events contemporary to Jan Austriak as well as those from earlier periods, for example from the year 1191 or 1241 . The subject matter of the indicated notes is diversified such as for example the information on shortening the fasting period from 1248 or on a donation of meadows to the monastery in Cracow, or on the murder committed in the church of St. Francis

\footnotetext{
8 'Provost Konrad, having lived through the full sixteen years of provostry, performing his work in a holy and praiseworthy manner, when all matters were settled and put in order in the best possible way, having performed a lot of good works and filled with good intentions, tired by old age and facing death, he piously secured himself for the final journey by the holy sacraments and changed his earthly life into eternal life. He was buried honourably in front of the great altar in the church'. See: ibidem, k. $5 \mathrm{v}$.

9 K. Łatak, Kongregacja krakowska kanoników regularnych laterańskich na przestrzeni dziejów, Kraków 202, pp. $175-176$.

10 S. Ranatowicz, Casimiriae civitatis, k. 5 v.

11 Ibidem, k. 6v.

12 Ibidem, k. 6.

13 Ibidem, k. 6v.

14 Ibidem, k. 6.

15 Ibidem, k. 6v.
} 
by the citizens of Cracow. Moreover, the chronicler provides information 'after historians writing on Polish matters', that at the beginning of the Kingdom of Poland history was not written down because Poles could not write ${ }^{16}$. As for the historians, the chronicler most often refers to Jan Herburt and Marcin Kromer.

Later, Jan Austriak was replaced by Grzegorz (1428-1439) to perform the function of a provost. According to Ranatowicz he was unanimously elected ${ }^{17}$ and described as vir singularis virtutis et doctrinae ${ }^{18}$. The information placed in the Chronicle on the activities undertaken by Grzegorz is not very extensive, however, there occurs information that he enlarged the monastery rooms with an infirmary, in which an altar was also built so that the sick could more easily listen to the Holy Mass ${ }^{19}$ and a new place for the library. One can also find there information on entering into confraternity with Cistercian monasteries. The death of Grzegorz was dated to 1439. The biography is followed, as in other lives, by notes referring to events of different years and without a strict chronological order. One of the most interesting ones is the information about the introduction of a silver coin in Poland in 1300, called the Czech groschen, which, according to that relation, was still to be used here and there in Cracow in $1670^{20}$. Noteworthy are also the records referring to the establishment of canon monasteries in Poland and their transfer to the order: in Trzemeszno in 965, and then in Czerwińsk, in 1222 in Mstów, and in 1358 in Kalisz. Moreover, there are some records here relating to Lithuania, for example a legend on the creation of Vilnius ${ }^{21}$. According to Guagninus, referred to by Ranatowicz, Prince Giediminas, the Lithuanian chieftain, had a dream during a hunt, when he took refuge in the mountains over the Vilnia River before nightfall. The indicated dream was explained by the priest Ledziejko, who dealt with divination and predicting the future. The wolf was to mean a strong and famous city, while other wolves in its interior, the population of that city. Therefore, on his advice, Giedymin decided to build a city on that hill and to name it Vilnius, from the name of the river flowing around the hill and to shift his headquarters from Trakai to Vilnius. It happened in 1305. Ledziejko, on the other hand, in recognition of his merits, was appointed an advisor in the city that was to be established and gained the name Radivil, from where the eminent family, one of the most splendid in Poland, came from. A note, mentioning the beginning of the Radziwiłł family, on the margin of card 9 is worth particular attention, because it had been written by someone else, certainly not by Stefan Ranatowicz ${ }^{22}$. There are some other entries which appear later and that relate to events in Lithuania, such as for example the settlement in Vilnius of a group of Tatars defeated by the Lithuanian Prince Witold during one of his expeditions; they were supposed to be there in times contemporary to the chronicler, forming

\footnotetext{
${ }_{16}$ Historici qui de rebus polonorum scripserunt narrant Polonos in principio Regni res gestas non scripsisse, eo quod nullam notitiam litterarum habuerunt, see: ibidem, k. 7.

17 Ibidem, k. 8.

18 Ibidem, k. 8.

19 Ibidem, k. 8.

20 Anno Virginei partus 1300. Venceslaus Rex Poloniae et Bohemiae, primus Monetam argenteam, grossos scilicet Bohemicos, in Poloniam intulit, qui ad huc in usu Cracoviae passim habentur, ad Annum 1670 et vocabatur Ceski grosz, see: ibidem, k. 9.

21 Ibidem, k. 9.

22 Radiviliarum familiae et stirpis origo, see: ibidem, k. 9.
} 
a separate community, professing their religion and having their own flag, worn in battles ${ }^{23}$. A passage on the rebellion of Vilnius citizens against the appointment of the local bishop, Bernard Maciejowski, coming from a Polish fmily, by King Sigismund III, is worth noting. Finally, Benedykt Woyna, a Lithuanian descent, was elected and the inhabitants of Vilnius forced the king to promise them to entrust similar dignity to people of Lithuanian descent ${ }^{24}$. Other pieces of information provided by Ranatowicz include entries on the earthquakes in Italy in 1618 and 1627; whereby he referred to Paweł Piasecki.

Gaspar (1440-1464) was the next provost. Ranatowicz provided the year 1467 as the date of his death, while in fact he was already dead in 1464, or might have resigned from office earlier ${ }^{25}$. Despite the fact that Gaspar stayed in power long, for 20 years, there is still little information about his accomplishments. The work started by his predecessors to continue the construction of the Corpus Christi Church, to which he was avidly devoted, came to the forefront ${ }^{26}$. Among different things, Ranatowicz mentioned the foundation of the canon monastery in Kurozwęki in 1451 and in the same year, the Franciscan monastery in Stradom, whereby he referred to the testimony of Maciej of Miechow ${ }^{27}$. According to the indicated account, in 1454 a canon monastery in Kłobuck was to be established by a historian Jan Długosz. In addition, the chapter devoted to Gaspar, includes a note on the Holy War against the Turks waged by the Pope Pius II in 1464 and the Jewish massacre in Kazimierz. Ranatowicz recalls the case three bishops at the same time were appointed in Cracow about 1456 as well as two extraordinary event, such as giving birth to 8 children simultaneously by a woman in Hungary and the case of the growth of new teeth observed in a nearly ninetyyears ol person, the mother of archbishop Stanisław Karnkowski: Medicus, Joannes dictus Oczko, vir in arte sua solertissimus, narravit, quod Matri Stanislai Karnkowski Archiepiscopi Gnesnensis accidisset, ipsi enim nonagenariae, dentes novis crevisse ${ }^{28}$.

After the death of Gaspar, Jakub of Wadowice (Vadovius), who governed in the years 1464-1495. Ranatowicz dated the moment of his death to 1477 , but it is difficult to state what he was guided by when he provided the indicated date as it is known that the provost lived many years later and his surname can be seen in the documents found ${ }^{29}$. Immediately after his nomination Jakub took up the work associated with the church construction, continuing the work of the previous provosts and enriching the interior of the church with four new altars and a wooden bell tower ${ }^{30}$. In addition, during the governance of Jakub Vadovius, a canon monastery was established in Kraśnik in 1468. It was also noted that in 1472 the Pauline monastery was introduced to St. Stanislaus's Church on Skałka in Cracow. Jan Długosz was involved in the indicated foundation and was buried there ${ }^{31}$. At that point, Ranatowicz referred to the description of Maciej of Miechów and also mentioned that the body of the

\footnotetext{
23 Ibidem, k. 9-9v

24 Ibidem, k. 9v.

25 K. Łatak, Kongregacja krakowska kanoników regularnych laterańskich, pp. 187-188.

26 S. Ranatowicz, Casimiriae civitatis, k. 10.

27 de quo Miechoviensis historicus Polonus, in haec verba scribit, see: ibidem, k. 10v.

28 Ibidem, k. 133.

29 K. Łatak, Kongragacja kanoników regularnych laterańskich, pp. 192-193.

30 S. Ranatowicz, Casimiriae civitatis, k. 12

31 Item ibidem depositum est corpus Joannis Dlugosii, Canonici Cracoviensis et Historici Poloni, et huius monasterii Fundatoris, Anno Domini 1480 defuncti, see: ibidem, k. $12 \mathrm{v}$.
} 
blessed Świętosława was buried on Skałka, her life was described according to the accounts of Joachim Bielski and Maciej of Miechów and was included in the chapter devoted to the achievements of Jakub Vadovius. Świętosława was an extremely pious inhabitant of Kazimierz, who after the death of her husband was involved in charity activity. She chose Saint Stanislaus, bishop and martyr, as her special patron, and when she prayed at his tomb on Skałka, St. Stanislaus appeared to her surrounded by the procession of other saints and ordered her to go to the Bishop of Cracow Lambert with the order to transfer his body to the cathedral in Cracow. The Blessed Stanisława took steps in this direction; she died in 1083 in the reputation of sanctity and was buried on Skałka. In the chapter devoted to Jacob of Wadowice, there is also information on various matters, Polish ones as well as the ones that referred to the situation in Europe, such as the introduction of a new calendar by Pope Gregory XIII in 1582, or the ban on reading the Talmud by Jews in 1593 by Pope Clement VIII and the discovery of the relics of Saint Cecilia in Rome in 1595. Ranatowicz used the chronicle of Paweł Piasecki ${ }^{32}$ as the source of his information. As an event worth mentioning in Poland was an exceptionally large flood of the Vistula River, which took place in 1475, when water poured even into the interior of churches and bridges connecting Kazimierz with Cracow were damaged. In addition, among the natural disasters the repeated hunger, plague and terrible drought in 1469 are mentioned.

The biography of Andrzej (1495-1505), the next provost, contains information which should be given in the case of his predecessor, Jakub Vadovius, because, as it was stated earlier, Ranatovicz incorrectly determined the date of death of the latter. Thus, Andrzej did not begin to act as a provost until 1495 and not 1477. Therefore, the history of the planned establishment of the Carthusian monastery in Kazimierz in 1478, about which Jan Długosz wrote, and which did not come into effect as a result of opposition from the inhabitants, had to take place during the governance of Jakub of Wadowice. In the next entry Ranatowicz reported that in 1489 the Blessed Stanislaw Kazimierczyk from the monastery of canons regular in Kazimierz died: Anno Domini 1489. B[eatus] Stanislaus Casimiritanus, vir sanctitate et doctrina illustris, ex claustro Casimiriensi Canonicorum Regularium, in caelos $a_{b i i t}{ }^{33}$. In addition, the chronicler wrote at this point that in 1670 he himself published the hagiography of the blessed Stanisław of his own authorship ${ }^{34}$, whereby he made a mistake in noting down the year, as it is known that in reality the indicated work was published in 1660 , i.e. ten years earlier. However, in spite of the mistake in dating, the aforementioned fragment is a proof that this part of the Chronicle, was certainly written down after the event as the text is continuous here and it is impossible to make the addition later. The hagiography placed in this chapter is short and limited to the most important events from the life of Stanisław Sołtys, called Kazimierczyk. The fragment is entitled Vita et obitus B[eati] Stanislai Casimiritani, Canon[ici] Regul[aris] professi Conven[tus] Casimirien[sis]. It also contains information about the origin and about the parents of the blessed, who at baptism was named after St. Stanislaus, bishop and martyr. From the very beginning, he was very talented, first at the parish school at the Corpus Christi church, and then at the Academy of Cracow, where he graduated in philosophy and theology, and finally obtained the title of

\footnotetext{
32 Ibidem, k. 13v.

33 Ibidem, k. 14v.

34 Ibidem, k. 14v.
} 
doctor. Being a man of great piety, he decided to join the Order of Canons Regular living in the Corpus Christi monastery in Kazimierz, according to the rule of St. Augustine. Here, too, he distinguished himself by his education, performing numerous responsible functions in the congregation, entrusted to him by his superiors, and by his zeal in piety. He often mortified his body and spent his days and nights praying and meditating. According to this account, when he prayed at the tomb of St. Stanislaus, Mother of God appeared to him together with her Son and St. Stanislaus and promised him the reward of eternal life for his pious life ${ }^{35}$. Just before his death, Christ was to appear to him in the midst of the Polish saints and call him to himself ${ }^{36}$. Interestingly, the words spoken during the revelations are not repeated literally in the history of the life of the blessed Stanislaus constituting a separate work, although the sense is the same; the differences are small, but they do exist, which would indicate that Ranatowicz did not copy this fragment from one hagiography to another. $\mathrm{He}$ died on 3 May 1489 in the reputation of sanctity. When the miracles that were happening through his intercession began to be noticed, after a few years his remains were excavated and placed in a new coffin in a different place of the Corpus Christi church. Ranatowicz wrote that there was such an inscription there: Hoc conclusa iacent Divi patris ossa sepulchro Stanislai, hac Casimiria de gente creati, Cuius gestorum miranda cerne trophea ${ }^{37}$. In 1635 the provost Marcin Kłoczyński ordered once again that the relics of the blessed Stanislaus were to be placed in the tomb in the altar in the left, side nave of the church ${ }^{38}$; the stone plaque built in there is located in this place to this day. In the times of Ranatowicz, people prayed at the grave of the indicated saint and asked for numerous graces through his intercession.

The life of Stanisław Kazimierczyk is followed by annal entries. Among other things, Ranatowicz described the history of Jews moving to Kazimierz in 1492 after the great fire in Cracow, where their houses burnt down. It was then that Jews started bringing fragrant herbs and roots to the provost and priests three times a year. This record deserves attention because the author made a reference on the margin of the card, referring to explanations on this matter up to the end of the Chronicle, to card 152: Aromata a iudaeis. Vide fol. 152. In this place there is an explanation of such a course of action, namely, a kind of compensation for the occupation of land from which, if they were inhabited by the Christian population, the church would have an income. The text on card 152 also bears a cross-reference, this time to card 15: this is a confirmation of great accuracy of Ranatowicz and diligence in writing the Chronicle. Then it is written that in 1505 a new provost was elected, initially as a coadjutor for Andrzej, who, due to illness and old age, could no longer perform his function ${ }^{39}$. Benedict was appointed, but according to Ranatowicz he held the office only for one year, while Andrzej was still alive; he was to resign himself and therefore the chronicler did not place his biography among the other prevosts ${ }^{40}$. In reality Benedykt served as a provost for more than ten years (1505-1518). The death of Andrzej is dated by Ranatowicz to 1505.

\footnotetext{
35 Gaudeo, fili Stanislae, de insigni tua ista devotione, qua me et S. Stanislaum prosequeris; viriliter age, te enim una cum sanctis meis, merces copiosa expectat $i$ caelis, see: ibidem, k. 15.

36 Surge (inquit) et festina, fili mi Stanislae, hodie enim mecum eris in Paradiso, see:ibidem, k. 15.

37 'The tomb contains the remains of the blessed Father Stanislaus, born of this House of Kazimierz, whose monument worthy to be admired is to be seen'.

38 Ibidem, k. 15v.

39 Ibidem, k. 16.

40 Ibidem, k. 16.
} 
Thus, some of the information contained in the life of the next governor of the Corpus Christi Abbey, Peter (1518-1526), refers still to the provostry of Benedict who was omitted from the list. In fact, Ranatowicz himself, writing about Peter's takeover of power, mentions two previous provosts ${ }^{41}$. He did not record much about his activities, explaining that he did not have adequate data from former writers and friars; he claimed that he preferred rather not to write anything at all than to make false information known: Hic praepositus, quae gessit per viginti annos et amplius, non scripsere antiqui, sed cum id non scribant, ideo etiam ego malui ignorare potius, quam divinare ${ }^{42}$. As a result of a mistake regarding the provostry of Benedict, Ranatowicz erroneously provided the information on the period of Peter's governance, because he was the provost for only eight years, and not twenty-one years. However, in general terms, the period of his governance was considered by the chronicler not to be very happy for the Kazimierz monastery. None of the events mentioned above seems to be particularly significant. Mainly the incidents of flood, fire, famine or pestilence were described. Peter's death according to Ranatowicz took place in 1526 . He also wrote quite extensively on priests' attempts to get married, giving examples of specific names, while he refers only once to the phenomenon of "spreading" heresy by Luther" ${ }^{43}$ However, he mentioned the spread of heretical thoughts in Poland. He also published some information about Pope Sixtus V and the huge estate of the Cracow bishop Andrzej Lipski, referring to the chronicle of Paweł Piasecki.

Jan Niczkonius (1526-1544) was another of the prevosts. Ranatowicz wrote a little more about his governance, which he considered to be successful for the congregation. He highly valued his character and education ${ }^{44}$, he also mentioned a number of merits that he had for the monastery, such as enriching the monastery library with his own books and transferring to a new place the parish school that operated by the Corpus Christi church. It is worth noting that although the longer Polish text appears only in the further pages of the Chronicle, it is here that the first Polish phrase appeared in the text, namely Ranatowicz noted that since then the place of the former location of the school was referred to as 'Stara Szkoła' ('Old school' $)^{45}$. Among the usual descriptions of natural disasters and various events, Ranatowicz mentioned the accident of burning the wife of one of the city councilors on the market square in Cracow, who was sentenced for switching to the Jewish faith; this incident took place in $1539^{46}$. Jan Niczkonius died in 1544. After noting his death, the chronicler quite extensively described the case of a nobleman, Jakub Melszyński from Brzeziny, who, surrounded by twelve companions, pretended to be Christ and his companions to be apostles; they wandered around Poland, committing numerous acts of looting and sacrilege, but were finally captured and punished in Silesia. This event took place during the reign of Sigismund the Old in 1507, while the author referred to Marcin Bielski and his Annales Polonorum in his description ${ }^{47}$.

\footnotetext{
41 In locum Andreae, vel potius Benedicti praepositi, subrogatus est omnium votis Petrus [...], villarum sub Andrea et Benedicto procurator, see: ibidem, k. 17.

42 Ibidem, k. 17.

43 Anno D[omi]ni 1517. Lutherus haeresim seminare incepit, Vitembergae, see:. ibidem, k. 18.

44 Ibidem, k. 19.

45 Ibidem, k. 19.

46 Ibidem, k. 19v.

47 Ibidem, k. 20-20v.
} 
Another portrait was dedicated to Stanisław Niedziela (1544-1582). Ranatowicz assessed his governance positively, emphasising his diligence and great contribution to the expansion and furnishing of the Corpus Christi church. In the margin of the card, he described the provost as operosus pater familias ${ }^{48}$.

In his description of merits of the indicated provost, he referred to the manuscripts of Father Krzysztof Łoniewski. He attributed the surrounding of the area of the monastery garden with a wall to Stanisław Niedziela, as well as the expansion of the monastery properties in Krzyszkowice, Swoszowice and Kamien, and the purchase of gold-plated crosses and new liturgical books from the Hungarians, and the construction of a new bell tower in place of the one destroyed by fire. He was also supposed to purchase two new bells named Stanislaus (or Dziad) and Augustinus (or Baba), which were still used by Ranatowicz's contemporaries in his time: [...] novasque campanas, praecipue duas Maiores, unam quam vocabatur hucusque communi cognomine Dziad, et alio nomine Stanislaus: et alteram Minorem dictam Baba, alio nomine Augustinus, comparavit ${ }^{49}$. It was also mentioned that two tenement houses in the vicinity of St. Lawrence's Church, together with gardens, were sold to Jews for the price of two thousand florins in gold ${ }^{50}$ and the handing over, also to Jews, many other objects and areas in Kazimierz. The case of the monastery in Kurozwęki is also worth mentioning . Well, after the death of the local provost Franciszek, the church was taken away from the canons by Mikołaj Lanckoroński, the landowner in Kurozwęki, called heretic by Ranatowicz, a significant part of the monastery and church resources were stolen, the land belonging to the convention was also taken over, while the two brothers remaining there were banished and returned to Cracow. Only after about thirty years, the provost of the Corpus Christi monastery submitted the matter to the royal tribunal, as a result of which it was ordered that the church and its property were to be returned to the Kurozwęki monastery, which, however, dragged on for a long time, so that only Paweł Łyczko became a provost in the regained monastery ${ }^{51}$. Additionally, a huge fire which took place in 1556 and which consumed a large part of Stradom and Kazimierz, was described. Ranatowicz clearly wrote that the bell tower near the Corpus Christi church burnt down at that time and in its place Jan Niczkonius ordered to build a new one, but he pointed out in the text that this had already been mentioned earlier ${ }^{52}$. The year 1582 was provided as the moment of death of Stanisław Niedziela. Immediately after the text concerning his biography, the short life of the saintly man, Valentin Kuczborski, also from the Order of Canons Regular in Kazimierz, was presented ${ }^{53}$. This monk was sent to the Bychov Monastery in Lithuania. He was distinguished by an exceptional holiness of life and a tireless proclamation of the Word of God ${ }^{54}$. He liked the hermitic life and stayed for some time far from the monastery, near the village of Ozierany, feeding only on bread received from the local inhabitants. However, he was later summoned back to the monastery

\footnotetext{
48 Ibidem, k. 21.

49 Ibidem, k. 21.

50 Ibidem, k. 21.

51 Ibidem, k. 21v.

52 Sub id tempus, turris cum quattuor campanis Ecclesiae nostrae SS. Corporis Christi combusta, in quo loco, Stanislaus niedziela praepositus, turrim novam, cum campanis, ut supra dictum est, excitavit et comparavit, see:. ibidem, k. 21v.

53 Vita Valentini Kuczborski Canon[ici] Regul[aris], see: ibidem, k. 23.

54 Ibidem, k. 23.
} 
and lived in a cold cell there, reading Scripture. He died in 1624 in the Bychov Monastery. Describing his life, Ranatowicz referred to Krzysztof Łoniewski and Piotr Jacek Pruszcz. The following section describes various events, including the jubilee celebrations in Rome in 1624, celebrated by Pope Urban VIII, during which Prince Władysław, the later King of Poland, was present and took part ${ }^{55}$. Ranatowicz also wrote about the disputes conducted in Toruń in 1625 by Catholics and as he described them, disidentes in religione Christiana.

After the death of Stanisław Niedziela, Stanisław Maniecki (1582-1611) was elected provost. Ranatowicz stressed quite strongly his involvement in state and church matters; he worked alongside the bishop of Cracow, Piotr Myszkowski, and also accompanied him at the Sejm in Warsaw, where he was to receive a document confirming the privileges of the Kazimierz monastery ${ }^{56}$. The fact that Stanisław Maniecki won the process and recovered the church and monastery buildings in Kurozwęki in 1593 was also noted. However, there is no data in the Chronicle on the continuation of work on the construction of the church. There is only information on the decorative elements. In turn, it is known that the church was destroyed by fire in 1595, when the church organ burned down. Ranatowicz generally saw in this provost 'a man of noble birth" ${ }^{57}$. However, during the period of his governance a lot of misunderstandings and confusion in the assembly occurred, not only in connection with the person of the imposed coadjutor during the period of Maniecki's illness. The indicated person began to allow too many of his relatives and persons connected with him to join him, he also took improper care of the monastic property and did not carefully observe the religious rule, which caused dissatisfaction and objections of many monks from the religious community, and consequently led to disputes and disagreements ${ }^{58}$. Serious problems occurred when in 1605 Stanisław Maniecki was paralysed, and it is known that he was seriously ill much earlier, as a result of which he was not able to properly perform his function..$^{59}$. It was then that a coadjutor, Paweł Łyczko, was appointed. at that time he was still a provost in the Kurozwęki monastery, but the congregation did not want to accept this choice and there were many misunderstandings and anxieties. The monks repeatedly appealed from this decision to the Holy See, until after numerous interventions, in 1608, the Bishop of Cracow Piotr Tylicki decided to nominate Tomasz Zdunek from the monastery in Kłobuck as an administrator in the Kazimierz community ${ }^{60}$. On the occasion of one of his appeals, Adam Sibovius was sent to Rome in 1607 as a member of the congregation. However, he died of some illness, and as he was characterised by an exceptional holiness of $\operatorname{life}^{61}$, he was surrounded by great respect from his confreres. He died in the reputation of sanctity and was buried in the Corpus Christi church, while extraordinary events began to take place at his tomb; the most frequent cases were cases of liberation of the possessed from the evil spirit. In writing about Sibovius, Ranatowicz referred to the account of Jan Gelazy

\footnotetext{
55 Ibidem, k. 23.

56 Ibidem, k. 24.

57 Ibidem, k. 24.

58 Ibidem, k. 24v.

59 Ibidem, k. 24v.

60 Ibidem, k. 25v.

61 Ibidem, k. 25.
} 
Żórawski, also a canon regular and exorcist ${ }^{62}$. Ranatowicz treated the fragment concerning Adam Siboviusz himself almost as a digression; after the end of this account he wrote: Sed ad praepositum nostrum redeamus ${ }^{63}$. Despite the election of a new administrator, the problem concerning the misunderstandings resulting from the imposition of the coadjutor's community was in fact resolved at the moment of Paweł Łyczko's death in 1610. On the other hand, Stanisław Maniecki himself died shortly afterwards, in 1611. His governance was not evaluated favorably by Ranatowicz. After the funeral, during the Chapter meeting it was decided that in future a provost from outside the Kazimierz community should be elected and the delegation went with such a request to the bishop. Ranatowicz still in this chapter, devoted essentially to the achievements of Stanisław Maniecki, included information about the election of Marcin Kłoczyński as the next provost ${ }^{64}$, although he also added a note to this passage at the end: Sed unde digressi sumus revertamur. He was not a monk at all, only after his nomination did he put on the costume of the Canons Regular, and only six years after his election did he become a monk ${ }^{65}$. The further part of the chapter described quite extensively the celebrations of the jubilee year 1603, under King Sigismund III as well as numerous church and state ceremonies that took place in Cracow on the indicated occasion. The chronicler also paid special attention to the huge number of people coming to Cracow from everywhere, so that they found it difficult to find accommodation not only in the city itself, but also in Kazimierz, as well as in the towns near $\mathrm{Cracow}^{66}$. He also noted the fact that the remains of the blessed Jan Kanty were found in the church of St. Anne in Cracow. Among the various events quoted at the end there are, among others, fragments written in Polish.

Another provost, Marcin Kłoczyński (1612-1644), as already mentioned, was elected from outside the circle of canons regular. Ranatowicz positively assessed his efforts at the beginning of the biography, claiming that he worked hard, as much as he could, to the best of his ability ${ }^{67}$. First of all, he completed the reconstruction of the church building from a wooden to a brick one, and especially, during his governance, the interior of the church was rebuilt. In addition to the renovation work, a number of ornamental works were carried out, magnificent and ornamental equipment was purchased, as well as books and dishes and liturgical vestments. During this renovation, the remains of the blessed Stanislaw Kazimierczyk were transferred to the new altar. The provost Marcin Kłoczyński was also a good host; he took care of the condition of the monastery rooms and all its buildings, as well as their appearance and comfort of use. He also renovated the buildings in the villages belonging to the monastery and erected new ones according to the needs of the monastery. He also made great effort to care about the matters related to the religious rule and spiritual life ${ }^{68}$. He cared for shaping young friars during the novitiate and introduced the position of a lector of philosophy and theology, he also organised public debates in the Corpus Christi

\footnotetext{
62 Ibidem, k. 25.

63 Ibidem, k. 25v.

64 Ibidem, k. 26.

65 Itaque Anno Domini 1612 Sabatho ante Dominicam Quinquagesimae, ad Ecclesiam SS. Corporis Christi solemniter introductus. Habitum regularem suscepit et portavit, non tamen nisi sexto post introductionem suam anno, professionem Canonicam fecit, see: ibidem, k. 26.

${ }^{66}$ Ibidem, k. 27v.

67 Ibidem, k. 28.

68 Ibidem, k. 29.
} 
church on St. Augustine's Day. He was also a supporter of fasting, modesty and simplicity of life among monks, in which he set an example ${ }^{69}$. By his conduct, he gained the approval of his superiors, who entrusted him with many different ecclesiastical and external dignities. The monastery of canons was now joined by more new monks and enjoyed the best reputation, which also resulted in new foundations for the monastery; Ranatowicz mentions such places as Bychów, Krzemienica, Sucha, Wolbrom and Antokol in Vilnius here as well. The period of Marcin Kłoczyński's governance was assessed very well by the chronicler: Sub huius felici gubernatione, caetus Canonicorum, maxime propagari et maiora in dies incrementa sumere coepit ${ }^{70}$.

In 1640, a coadjutor in the person of Father Jacek Liberiusz, a doctor of theology and a contemporary lecturer of philosophy in the Corpus Christi monastery, joined the provost ${ }^{71}$. Marcin Kłoczyński died on February 8, 1644. While publishing the information about his death, Ranatowicz once again emphasised that the time of his governance was very successful and fruitful for the monastery: Vir insignis. Cuius cum tota praepositura prosperum haberet successum, hoc unum defuit, ut diutius in munere praepositurae versaretur longiorique temporis spatio ipsius officium compleretur ${ }^{72}$. His successor, Jacek Liberiusz, funded a gravestone plaque for him, the content of which was quoted in the Chronicle: Admodum Reverendo Domino Martino Kłoczyński i.V.D. Ecclesiae Conventusque huius praeposito, ac iudicii synodali. Viro in omni vita sua integerrimo ac inculpato. in laboribus Ecclesiasticis indefesso. in sententia ferenda recto. in promovenda regulari disciplina ferverventissimo. Qui Ecclesiam hanc, varia pretiosa supellectili, Monasterium permultis aedificiis: Congregationem plurium Monasteriorum coloniis: in magnum quoque Ducatum Lituaniae ex hoc coenobio deductis, ampliavit et illustravit. Obiit plenus dierum ac meritorum. Anno Domini M.DC.XL.iV Die Viii Februarii. Aetatis 82. Perge Viator, similesque Praepositos, Huic Ecclesiae Apprecare ${ }^{73}$. The next part of the chapter mentions people from Kazimierz who can boast glorious achievements in the field of science and work for the city and the monastery, including, for example, the later provost Jacek Liberiusz and Paweł Pukal, the author of the Genealogy of Canons Regular of the Lateran ${ }^{74}$. Among the various events described below, the following were once again recorded: the riots and crimes committed by Jews in Cracow, this time in 1636, the construction of a new synagogue in Kazimierz in 1639, the ceremonial entry of King John Casimir into Cracow in 1649, and two additional

\footnotetext{
69 Ipse ab omni luxu, ambitione, servorum strepitu, aliaque mundana ostentatione, remotus; abstinentiaque clarus, see: ibidem, k. 29v.

70 Ibidem, k. 29v

71 Ibidem, k. 32.

72 'An eminent man. While his entire work on the provostry was successful and beneficial, only one thing was missing: he was not able to perform his duties for a longer period of time', Translated into English, basing on the author's own translation into Polish, see ibidem, k.33.

73 'To the highly honoured Marcin Kłoczyński, doctor of both laws, the provost of this church and monastery. A man who was unblemished and impeccable throughout his life. Tireless in the church works. Indefatigable in the exercise of lawful judgment. Zealous in expanding monastic discipline, who graced and ornamented the church with various valuable vessels and the monastery with many buildings: he enlarged the congregation with numerous branches of the monastery, also in the Grand Duchy of Lithuania, from which the monastery originated. He died in full merit, in the Year of the Lord 1644, on February 8th, at the age of 82. If you are a passer-by, please, stop for a moment and pray for similar provosts for this church'. See: ibidem, k. 33.

74 Ibidem, k. 30v
} 
short biographies of monks of exceptional holiness ${ }^{75}$. One of them was Albertus Tarnovius Sowiński, a man of extraordinary piety, who was constantly praying and meditating. He also frequently fasted, repented and mortified. He died in the monastery in Sucha in 1636 and was buried there. The second monk described was Mikołaj from Radomsko. He also lived in great poverty, often eating bread and water and giving other food products to the poor. He stayed awake, prayed, and taught the principles and truths of the Christian faith to others with great pleasure. He died in 1610 .

The last of the governors of the Corpus Christi Provostry, whose biography Ranatowicz published in full, was Jacek Liberiusz (1644-1673). At the very beginning, the chronicler pointed out that his election to the post of the provost was unanimous and that everyone was in favour of him: [...] tanto omnium fratrum Canonicorum applauso, ut nemo fuerit, qui non ei hunc honorem gratularetur. Episcopus quoque Cracoviensis Petrus Gembicki, propensum suum erga illum animum declaravit, cum confirmationem ipsius gratam habuerit ${ }^{76}$. He also stressed his good birth and education: he studied at the Cracow Academy, where he was awarded a master's degree in philosophy and then a doctor's degree in theology, and he also spent some time in Rome and Milan. He gained the recognition of his superiors because he was entrusted with various important functions, including the appointment by Andrzej Trzebicki, Bishop of Krakow, censor of the published books in the diocese of Cracow ${ }^{77}$. Ranatowicz also recognised Jacek Liberiusz as a good host of the monastery estate. He redecorated and repaired the damage caused by the Swedish army, but also started new investments and enlarged the property of the monastery, for example by buying new tenement houses for its use. Many elements of the monastery buildings were restored and improved during his provostry, and the liturgical books in the Corpus Christi church were enriched. The temple itself was already completed at that time and even renovated under the governance of the previous provost, Marcin Kłoczyński, but now, among other things, a new chapel of the Mother of God was built, new altars and benches were erected, and the organs were installed to replace the previous, destroyed ones. A new chapel, called the Gethsemane, was also built in the cemetery ${ }^{78}$. Jacek Liberiusz was, according to Ranatowicz, a good superior and a guardian of the parish under his authority ${ }^{79}$. He was also a zealous preacher, which resulted in the publication of a collection of sermons dedicated to the Bishop of Cracow, Piotr Gembicki, under a common title: Gospodyni nieba y ziemie naświętsza Bogarodzica Marya; innego zbioru, zatytułowanego: Gospodarz nieba y ziemie Chrystus Jesus, which was dedicated to the next bishop of Cracow, Andrzej Trzebicki, and another one: Gwiazda morska, naświętsza Panna Marya, dedicated to the Polish king Michał Korybut. There are many achievements of the provost placed in the Chronicle, and it is not possible to mention them all especially since the author himself clearly limited himself to providing only the most important ones, because he wrote: in summa, quidquid pro Ecclesia sua et Conventu fecit, scripsit, addixit, difficile dictu, quantum de charissima sibi sponsa merebatur ${ }^{80}$.

\footnotetext{
75 Ibidem, k. 34v, 35 .

76 Ibidem, k. 36.

77 Ibidem, k. 36v.

78 Ibidem, k. 36v.

79 Ibidem, k. 36v.

$80 \quad$ Ibidem, k. 37.
} 
Ranatowicz was a friend of Jacek Liberiusz, his favorable attitude towards the actions of the provost can be seen in many places on the pages of the Chronicle, even in his own opinion: ipse innata benignitate, prudentia, gravitate, modestia conspicuus, futurisque saeculis, et posteris invidendus, ob morum suavitatem, mansuetudinem et pudicitiam, cunctis acceptus ${ }^{81}$. Among the various events described in this chapter, Ranatovich mentions, for example, the devastation of Ruthenia by the Cossack army under Khmelnytsky's command in 1648; he also blames the Cossacks for the murder of many inhabitants and monks in Krasnik and the destruction of the local church and monastery ${ }^{82}$. This event was told very accurately, while the funeral of King Władysław IV and the coronation of King John Casimir were treated superficially, with only a short note stating the date. In addition, a huge plague was mentioned, which in the years 1651-1653 claimed a lot of victims; the number of citizens of individual cities who died because of it was mentioned on the margin of the card ${ }^{83}$, However, the total number of victims in Cracow, Kazimierz and the surrounding towns was estimated at 35 thousand 638 people. It is probably the plague during which the chronicler's parents died. Ranatowicz devoted much attention to the invasion of Swedish troops under the command of King Charles Gustav in 1655 and their stay in Cracow and Kazimierz. The Swedes stayed in the Corpus Christi monastery for about a month and inflicted many destructions and lootings ${ }^{84}$. At that time many documents and books were lost, many valuable liturgical equipment and vessels were stolen, and the Blessed Sacrament was desecrated when the host was abandoned in the cemetery after the gold monstrance had been stolen. Ranatowicz also mentioned the robbery of the most valuable collections of the monastery library, including the works of St. Augustine. When describing the matter of establishing a tax called 'tax per head' (contributio capitalis), the number of people in the parish of Corpus Christi in 1661 was given: according to Ranatovich it was 1518 people. Mention was also made of the issue of tithes given to the monastery in Sucha Beskidzka in 1665, when Jan Ignacy Naramowski was the provost of the local monastery. The document regulating the indicated claim was issued by Bishop Andrzej Trzebicki; Ranatowicz copied it entirely in his Chronicle and placed it as a sticker between the cards $41 \mathrm{v}$ and 42 . He even marked the place where the bishop's seal was located ${ }^{85}$. On the back of the sticker there is a text about the rebellion of certain monks and the solution of this matter, but not related to the attached document. In this chapter there are several references to the riots in the Jewish district of Kazimierz, in which Cracow students often took part.

In 1666, a coadjutor was assigned to the provost, and it was Victorin Wereszczyński ${ }^{86}$. Jacek Liberiusz zmarł w roku 1673. Ranatowicz, when writing about his death, once again underlined his merits for the congregation and his distinctive personality traits; he even described the appearance of the provost, ultimately defining him as: toto denique habitu decorus $^{87}$. He also placed an additional note on the margin of the card concerning the

\footnotetext{
$81 \quad$ Ibidem, k. 37.

82 Ibidem, k. $37 \mathrm{v}$

83 Ibidem, k. 38

84 Ibidem, k. 38.

85 Locus sigilli, see: ibidem, wklejka pomiędzy k. 41v i 42.

86 Ibidem, k. 42v.

87 Ibidem, k. 44.
} 
multiplication of financial resources by Jacek Liberiusz left by his predecessor Marcin Kłoczyński ${ }^{88}$. After the death of Liberiusz, his successor Wiktoryn Wereszczyński founded a plaque in the Corpus Christi church to commemorate the deceased provost: Hyacinthus Liberius. Unicum integritatis et Religionis Exemplar, Emensis in Canonico Ordine quinquaginta sex annis, omnigenarum virtutum reliquit post se vestigia. Divinioris sapientiae suffragio, ad supremam Theologici gradus lauream evectus, alienae sapientiae Censor et Arbiter esse meruit. Praepositi Generalis dignitate insignitus, eam, suavitate morum, vitae exemplo, rerum peritia, agendi gratia, per viginti novem annos, et amplius, ita administravit, ut omnium amores et laudes mereretur. Tandem laboribus et doloribus gravissimis confectus, vitam quam Ecclesiae et Religioni impenderat, naturae deposuit. Anno aetatis suae septuagesimo quarto. Christi M.DC.LXXiii. Die 23. Octobris ${ }^{89}$.

In the list of friars who died under the provostry of Jacek Liberiusz, the names of some of the friars are often mentioned, along with their particular achievements and merits, their functions and the information known to the author about their lives. This is the case with the obituary of Valentin Świechowicz (+1667), Krzysztof Łoniewski (+1656), Piotr Śmiarowski $(+1655)$ and Jan Gelazy Żórawski (+1645). Most of them knew Ranatowicz personally. However, in the obituary of his brother Augustine, there is no mention of the relationship between them ${ }^{90}$. Perhaps it was a deliberate act, as a monk in the then sense should have died to the outside world, should have abandoned contacts with his previous life, and the sign of it was taking a new name in the religious vestition. In any case, the chronicler wrote almost nothing about his family, or at least did not underline his family ties in any way, even if he mentioned someone from his family in the Chronicle.

The last of the Corpus Christi monastery governors described in the Chronicle was Wiktoryn Wereszczyński (1673-1694). Ranatowicz, however, did not include his biography as he died while the provost was still alive. After preparing the title page of the hagiography and entering the surname, he left a free space for a description of achievements. Then, as in previous biographies, he related various events, which took place during the provostry of Wereszczyński. He also started entries with obituaries for monks who died during the indicated period, but he did not finish the task. He left many blank cards to be completed in the following years, both after the notes of the years in which this Prefect had been in power and after the list of deceased brothers had been drawn up. He was prevented from doing so by death, since, as we know, he died in 1694. Ranatowicz probably planned to continue and finish the chronicle, which is indicated, for example, by leaving an empty space after the biography of the last of the above mentioned provosts. Although the biography itself was written by another author, Ranatowicz included a lot of information on Wiktoryn Wereszczyński's

\footnotetext{
88 Ibidem, k. 44

89 Jack Liberius. He was an example of exceptional righteousness and piety. Having lived in the canons' order for 56 years, he left behind signs of all kinds of virtues. He was elevated to the highest degree of glory in theology with the help of divine wisdom and deserved to be a censor and a judge because of other knowledge. He was distinguished by the dignity of the General Provost, he governed the provostry so well for 29 years and more, by the gentleness of customs, by the example of life, by experience in all matters on account of his actions that he deserved the love and praise of all. Exhausted by the hardships and heavy suffering, he gave up his life, devoted to the church and monastery, at the age of 7. In the Year of the Lord 1673, on October 23rd. Translated into English, basing on the author's own translation into Polish, see ibidem, k. 44.

90 Augustinus Floridus Ranothowicz. Casimiriensis, professus domus nostrae, presbyter. Obiit in Conventu Cremenecensi. Anno Domini 1657, die 8 Julii. in Religione anno 19, see: ibidem, k. 46v.
} 
activity in his account of the individual events. Thus it is known for example about the consecration of the altar in the chapel of Mother of God and another altar in the chapel on the cemetery ${ }^{91}$. There are also numerous references to the public disputes organised in the Corpus Christi church. It was also noted that the Provost of Lithuania went to the General Chapter congregation in 1685 to the monastery in Krzemieniec ${ }^{92}$. The chronicler devoted much attention to the description of the plague, which in 1678 killed a huge number of people in Kazimierz ${ }^{93}$ and other elementary disasters such as floods, drought or fire. From Card 54 , exactly from the description of the events of 1683, Ranatowicz switched to the Polish language, and continued this account until the list of monks who died at that time. This description concerns the way in which monks dress in various congregations, for example St. Bernardines and Carmelites ${ }^{94}$. When listing the deceased brothers, Ranatowicz often provided additional pieces of data, such as the way in which they left this world and others; these were probably events of which he knew from the direct accounts of witnesses ${ }^{95}$. He also managed to record that in 1693 Wiktoryn Wereszczyński contracted a serious illness and was asked to appoint a coadjutor; Michał Rusiecki, then the provost of the Vilnius Convention and in later years, at the Corpus Christi monastery in Kazimierz (1694-1706), was elected. At the very end of this chapter, after a series of unrecorded cards, there is a piece of information still forgotten earlier, with a note: to się pisze teraz, co się opuścito na swym miejscu (It is now written what has been omitted earlier), concerning the process of a certain guild of shoemakers with the Corpus Christi parish priest, who at that time was still Marcin Kłoczyński, in $1640^{96}$.

Each of the reports on the achievements of individual provosts is closed with a list of monks who died under his governance. It is obvious that more information about the life and achievements of the deceased brothers was given to the chronicler in the case of deaths in later, closer or modern years. He knew many of the monks personally, and heard many things about others from his confreres. Certainly, especially in the case of entries from previous years, he also used the obituary of the monastery. In total, Ranatowicz listed 320 deceased canons in his obituaries, including 50 from the Kraśnik Convention, while the list of those entered in the Chronicle should include two more entered after the death of its author ${ }^{97}$. Additionally, there are entries of the deceased benefactors of the Kazimierz Monastery ${ }^{98}$.

As it results from reading the biographies of the provosts, the author did not limit himself to giving facts from the religious life. His accounts contain a lot of valuable information about events taking place in Cracow and in the whole Poland, and are a valuable source for research on culture and issues of everyday and religious life in Cracow and Kazimierz in the 17 th century.

\footnotetext{
$91 \quad$ Ibidem, k. 51v.

92 Ibidem, k. 56.

93 Ibidem, k. 53, 53v.

94 Ibidem, k. 54.

95 Jan Ignacy Naramowski, died in a fire in 1677; Jacek Wyczawski, died in 1678 of a plague treating the sick with sacraments; Benedykt Adam Samotulski, died suddenly in 1686, see: ibidem, k. 57.

96 Ibidem, k. 80.

97 Ibidem, k. 58v.

98 Ibidem, k. 10v.
} 
The report from the Chronicle by Stefan Ranatowicz CRL (1617-1694) on the biographies of the provosts of the Corpus Christi monastery of Canons Regular of the Lateran - Krakow Congregation (from Konrad Aleman to Wiktoryn Wereszczynski) Summary

The presented article is a discussion of biographies of 13 subsequent provosts of the monastery of Canons Regular of Lateran of Krakow Congregation, at the Corpus Christi church in Kazimierz district. The author of the chronicle, father Stefan Ranatowicz, lived in the years 1617-1694, in Kazimierz near Krakow, where he learned at the parish school at the Corpus Christi church and studied at the Krakow Academy (in the years 1635-1636). In the autumn of 1636, he joined the congregation of Canons Regular of Lateran. He was one of the leading historiographers of his order. His most important work is the Chronicle with the Latin title: Casimiriae civitatis, urbi Cracoviensi confrontatae, origo. in eaque ecclesiarum erectiones et religiosorum fundationes, nec non series, vitae, res gestae praepositorum Conventus Canonicorum Regularium Lateranensium S[ancti] Augustini ad Ecclesiam S[acratis]S[imi] Corporis Christi descriptae a Stephano Ranothowicz eiusdem conventus et Ecclesiae Canonico Regul[ari] professo. Its main section contains biographies of provosts of the Krakow monastery, from Konrad Aleman to Wiktoryn Wereszczyński. Apart from topics related directly with monastic matters, the author also discussed many issues relating to daily, religious, as well as cultural life of Kazimierz and Krakow, and also often mentioned social and economic matters concerning also the entire Polish State.

Keywords: Historiography, regular canon, biography, historical and cultural events.

About the author: Małgorzata Pęgier, $\mathrm{PhD}$ - assistant in the Department of Historical Auxiliary Sciences at the Institute of Historical Sciences of the Cardinal Stefan Wyszyński University in Warsaw (UKSW). Scientific interests: seventeenth-century monastery literature, monastery historiography, Latin modern literature. 